\title{
Macrofauna Settlement on Pearl Oyster Collectors in Kenya: Seasonality and Abundance
}

\author{
Edward N. Kimani ${ }^{1}$, Kenneth M. Mavuti ${ }^{2}$, Titus K. Mukiama ${ }^{3}$ and N. Wambiji ${ }^{1}$ \\ ${ }^{1}$ Kenya Marine and Fisheries Research Institute, P.O. Box 81651, Mombasa, Kenya; ${ }^{2}$ Department of Zoology, University \\ of Nairobi, P. O. Box 30197, Nairobi; ${ }^{3}$ Department of Botany, University of Nairobi, P. O. Box 30197, Nairobi
}

Key words: Pearl oysters, seed collection, macrofauna, bivalves, settlement, monsoon seasons, Kenya

\begin{abstract}
Collection of pearl oyster seed using artificial collectors is a critical step in the production of cultured pearls. This paper reports the seasonal abundance of macrofauna, which settled on spat collectors set to collect Pinctada margaritifera and Pteria penguin seed in shallow inshore areas at Kisite and Mombasa, Kenya. In both, settlement of macrofauna and bivalves was higher during the northeast monsoon season than the southeast monsoon season. Ascidiians and Sabellidae were significantly more abundant on collectors during the southeast monsoon season. A few bivalve species of commercial value including: P. penguin, Perna viridis and Anadara antiquata also settled on collectors during the southeast monsoon. Multivariate analysis showed the periods April-June and June-October presented significantly different macrofaunal assemblages in the open lagoon environment at Mombasa, whereas a significant difference occurred between assemblages settled during June-October and October-January in the channel environment in Tudor. Seven $P$. penguin specimens were obtained from 41 spat collectors in Kisite, whereas one $P$. margaritifera and three $P$. penguin specimens were obtained from 40 spat collectors deployed in Tudor Channel during the southeast monsoon period. From the results, settlement of $P$. margaritifera appears to be episodic and needs long term monitoring to determine the environmental and oceanographic conditions that are associated with its recruitment, whereas $P$. Penguin settlement occurred mainly during the southeast monsoon season.
\end{abstract}

\section{INTRODUCTION}

Interest in pearl culture in the Western Indian Ocean region is rapidly increasing. This is demonstrated by commercial production in Seychelles and introduction of a community based pearl culture venture in Mafia Island, Tanzania (Rice et al., 2006). Pearl oyster larvae and juvenile culture techniques in hatcheries have been successfully developed (e.g. Southgate \& Beer, 1997; Rose \& Baker, 1994), however, seed collection from the wild, using various materials suspended mid-water, is the main source of pearl oyster seed to date, due to the high costs of land-based hatcheries. The advantages of collecting culture seed from the wild are low cost and simplicity, but the main disadvantage is the dependence on the natural recruitment process, making the results highly variable from season to season and place to place.

Apart from seed collection, settlement on artificial spat collectors has been used to explore the recruitment dynamics of commercial bivalves and other benthic species (Haven \& Fritz, 1985; Knuckey, 1995), and the interactions of abiotic factors with benthic populations and their abundance (Sumpton et al., 1990; Thouzeau, 1991). Recent studies have focused on determining optimal emersion time (e.g. Monteforte \& Garcia-Gasca, 1994; Friedman \& Bell, 2000), depth range (e.g. 
Cabral et al., 1985; Sims, 1993), efficiency of collector materials (e.g. Cashmore et al., 1998; Coeroli et al., 1984) and population dynamics on the collectors (e.g. Friedman \& Bell, 2000; Thouzeau, 1991). A few studies have examined settlement patterns and the role they play in regulating and structuring marine invertebrate populations in West Indian Ocean. These include the settlement of mangrove oyster, Saccostrea cucullata within the intertidal zone in Kenya (Van Someren and Whitehead, 1961) and in South Africa (Dye, 1990), and recruitment of the sea urchin Echinometra matheai in Kenya (Muthiga, 1996). These studies demonstrate that settlement of benthic species in the region is seasonal and also determines future abundance and the population structure of some species. This paper reports the results of two experiments conducted in Kenya between 2002 and 2005. These involve the recruitment of macrofauna onto spat collectors set to assess the abundance and settlement patterns of pearl oysters, mainly the blacklip pearl oyster Pinctada margaritifera and the winged oyster Pteria penguin. The objective was to determine the recruitment seasonality and abundance of pearl oysters and associated macrofauna and to determine the optimum season for pearl oyster spat collection.

\section{MATERIALS AND METHODS}

A range of different type of settlement collectors were deployed in Mombasa and in Kisite-Mpunguti Marine Protected Areas (MPA) and in the Tudor Channel (Figure 1) between October 2002 and recovered last in June 2005. Kisite is a relatively small coral outcrop island, approximately $4 \mathrm{~km}$ offshore. The experiment site, on the leeward side of the island, has a sandy bottom and depth of about $5 \mathrm{~m}$ gradually increasing with distance from the island. The study sites in Mombasa were at Tudor Channel and in a shallow lagoon within Mombasa MPA. The Tudor Channel is approximately $25 \mathrm{~m}$ deep and drains Tudor creek. It is has no permanent river, but the environmental factors, salinity and the quantity and quality of suspended matter, are influenced by freshwater run-off during the rainy season. The bottom of the study site is covered by dead coral rocks, live soft corals and sand. The study site at the Mombasa MPA is sheltered by a continuous reef that opens to the sea through a channel at the south. Water fills the lagoon by flowing over the reef and channel during high tide and flows out through the reef and channel during low tide. The lagoon water is therefore oceanic with a low residence time. The bottom is covered by seagrass, scattered coral stands and bare sand. The sites represent typical inshore environments common in East Africa that might be used for pearl oyster culture.

Two experiments were conducted to determine the abundance of macrofauna that settle during the Southeast Monsoon (SEM) and Northeast Monsoon (NEM) seasons. Collectors were deployed at the leeward side of Kisite Island, between October 2002 and September 2003, and in the Mombasa MPA and the Tudor Channel between July 2004 and June 2005. These sites were chosen because studies have shown that pearl oyster settlement is higher within calm sheltered areas (Friedman \& Bell, 2000). The spat collector unit was $45 \mathrm{~cm}$ long 10 $\mathrm{mm}$ diameter nylon rope, folded once as described by Victor et al. (1987). A total of 124 spat collectors were deployed and recovered from Kisite during the study period. Of these collectors, 84 were free nylon rope collectors tied onto four $10 \mathrm{~m}$ long lines, deployed at four sites along the leeward side of Kisite Island during the NEM and SEM for between season comparisons. The four lines, with a total 43 free nylon rope collectors were first anchored during the NEM season from 12 October 2002 to 13 March 2003 (152 days). Forty-one spat collectors were washed with freshwater and sun-dried for ten days before re-deployment to the four sites on 26 March 2003 during the SEM season; they were recovered on 9 September 2003 after 162 days. During the same period, experiments to determine the influence of collector size on abundance of settled fauna were conducted. Forty spat collectors in replicates of one, two, three and four nylon rope bundles, together with full, half and quarters of used onion-bag net material, were deployed on a single long line and between three and eight replicates of each size of the two types of collectors were also tied at random on a separate 40-meter long line.

No $P$. margaritifera spat were found on the collectors in the above two experiments. Therefore, collectors were deployed in the Tudor Channel to assess the abundance of $P$. penguin at that site. This 


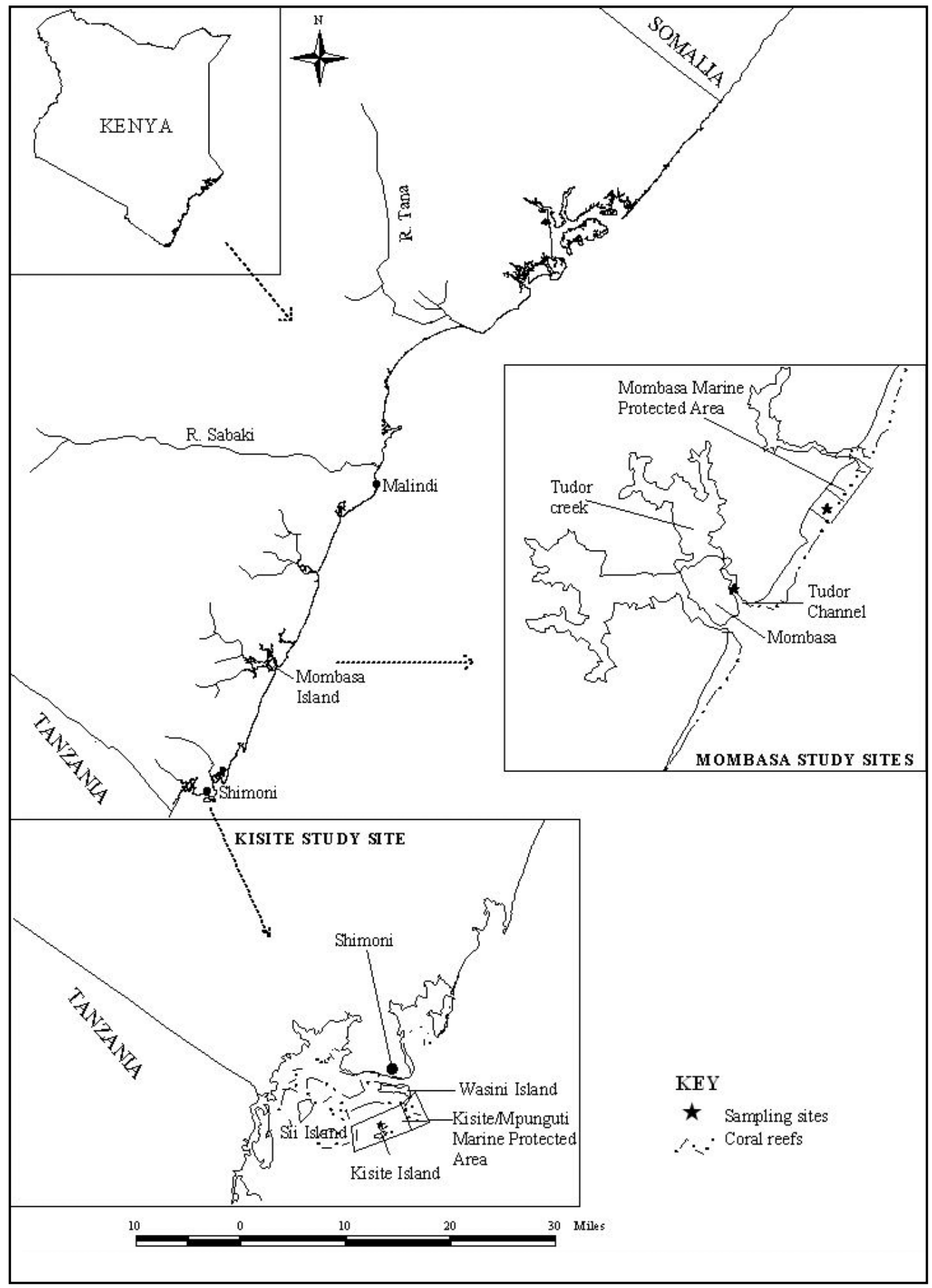

Fig. 1. Map of Kenya coast showing study areas Tudor channel and Mombasa Marine Protected Area, and Kisite within Kisite-Mpunguti Marine Protected Area. (Adapted from East Africa Atlas of coastal resources UNEP EAF/14 Project) 
species is a good alternative to $P$. margaritifera in pearl production and is usually abundant in deep current-swept habitats (Knuckey, 1995). Between seven and ten black plastic sheets were deployed in the two areas during April 2004 and recovered at approximately three month intervals during July 2004, October 2004, January 2005 and April 2005. Eight nylon rope collectors, seven onion-bag net collectors, five mosquito net collectors and six white plastic sheet collectors were deployed within the Mombasa MPA between August 2003 and January 2004 to test the efficiency of different types of spat collectors. The size of the nylon rope collector unit was the same as in the earlier experiments and the size of the plastic sheets and net material was $37 \times 74 \mathrm{~cm}$, similar to the size of onion-bag nets. In this study, a cover was used to protect the collector material. The collectors were folded into perforated plastic baskets with bottom diameter $22 \mathrm{~cm}$, a top diameter of $30 \mathrm{~cm}$ and height of $18 \mathrm{~cm}$ and with openings of 0.6 by $0.5 \mathrm{~cm}$. Eight rectangular holes $(5.5 \times 4.0 \mathrm{~cm})$ were cut out of the side and four on the top covers to increase water circulation around each collector. Each collector unit was then tied on a $2 \mathrm{~m}$ vertical line, anchored with a concrete block and a buoyed with a plastic bottle. The collector units were set 10 to $15 \mathrm{~m}$ apart, approximately 2 to $3 \mathrm{~m}$ depth at spring low tide, parallel to the reef in Mombasa MPA and parallel to the shoreline in Tudor Channel. On recovery, all organisms were physically removed from the collectors and identified using available literature (Abbott \& Dance, 1982; Richmond \& Rabesandratana, 1997; Shirai, 1994). To ensure correct identification during this experiment, all the pearl oysters were held in the sea in similar plastic baskets, without additional perforations, and examined again after three months.

The normality of the distribution of the macrofaunal abundance data was tested using the Shapiro-Wilk's W test, and homogeneity of variance were compared using Levene's test on $\log _{10}(x+1)$ transformed data. The non-parametric Kruskal Wallis test was performed to determine significant differences in abundance of species and taxonomic groups during the four study periods, followed by Mann-Whitney U test for two samples comparisons, where significant differences were occurred. PRIMER (Plymouth Routines In
Multivariate Ecological Research) was used to perform hierarchical clustering, with group average linkage with forth root transformed data with BrayCurtis similarity measure, followed by Analysis of Similarity (ANOSIM), to assess differences in macrofauna assemblage between sampling times, and SIMPLER to identify the key species that are drivers or strongly influencing any detected differences.

\section{RESULTS}

\section{Abundance of macrofauna on spat collectors}

The species and/or taxa of macrofauna on spat collectors deployed in Kisite during the SEM and NEM seasons from October 2002 to September 2003 are listed in Table 1. Six of the 124 collectors had no macrofauna at all, 70 had between one and 20 macrofauna individuals, 20 had between 20 and 40 individuals, and the rest 30 collectors had $>40$ individuals. Bivalves made up $80.7 \%$ of the 3,478 macrofauna removed from 124 collectors including the 40 collectors from the collector-size experiment during the two periods. Polychaetes, mainly the tube dwelling family Sabellidae, made up 8.2\%, while trumpet worms (family Sipunculidae), made up $4.3 \%$ of the total number of macrofauna. Echinoderms, starfish and sea urchins, made up $1.5 \%$, gastropods $1.4 \%$, and crustaceans, mainly crabs made up $1.1 \%$ of the macrofauna recorded. The bivalves were dominated by two mussel species, Septifer bilocularis (46.4\%) and Perna viridis $(9.3 \%)$ together making up $55.7 \%$ of the total number of bivalves. The pearl oyster Pinctada imbricata and Pinctada nigra made up $17.6 \%$ and $2.1 \%$ of the total number, respectively. Scallops were dominated by Chlamys senetaris and comprised 1.8 $\%$ of all bivalves. During the SEM season, seven $P$. penguin were obtained from 41 nylon rope collectors and four more were obtained from the 40 onion-bag collectors, deployed for the collector size experiment. Other bivalve species with commercial potential included $P$. viridis, Chlamys senatorius, and Anadara antiquata contributing 2.6\%, 0.3\% and $0.1 \%$ of the macrofauna respectively. 
Table 1. Abundance of species/families (mean $\pm \mathrm{SE}$ ) per nylon rope collectors during the southeast and northeast monsoon seasons at Kisite between October 2002 and September 2003. ${ }^{*}=$ significantly higher at $p<0.05$ )

\begin{tabular}{|c|c|c|c|c|}
\hline \multirow{2}{*}{ Species/Family } & \multicolumn{2}{|c|}{ Northeast monsoon } & \multicolumn{2}{|c|}{ Southeast monsoon } \\
\hline & Mean $( \pm$ SE) & No & Mean ( \pm SE) & No \\
\hline Anadara antiquata & 0 & 0 & $0.05 \pm 0.034$ & 2 \\
\hline Barbatia decussata & $0.4 \pm 0.18$ & 20 & 0 & 0 \\
\hline Chlamys senatorius & $0.1 \pm 0.06^{*}$ & 5 & $0.02 \pm 0.02$ & 1 \\
\hline Cymatium muricinum & $0.2 \pm 0.09$ & 8 & $0.1 \pm 0.04$ & 3 \\
\hline Haliotis pustulata & $0.1 \pm 0.06^{*}$ & 6 & $0.05 \pm 0.034$ & 2 \\
\hline Isognomon isognomon & $0.02 \pm 0.023$ & 1 & $0.02 \pm 0.024$ & 1 \\
\hline Lima lima & $0.3 \pm 0.14 *$ & 11 & $0.02 \pm 0.024$ & 1 \\
\hline Malvufundus normalis & $0.2 \pm 0.06$ & 7 & $0.6 \pm 0.21^{*}$ & 24 \\
\hline Medaeus granulosus & 0 & 0 & $0.02 \pm 0.024$ & 1 \\
\hline Musculus cumingiana & $0.2 \pm 0.07$ & 8 & $0.05 \pm 0.034$ & 2 \\
\hline Musculus senhousia & $1.8 \pm 0.34 *$ & 77 & $0.02 \pm 0.024$ & 1 \\
\hline Pachygrapsus minutus & 0 & 0 & $0.02 \pm 0.024$ & 1 \\
\hline Perna viridis & 0 & 0 & $1.1 \pm 0.33$ & 47 \\
\hline Pinctada imbricata & $6.8 \pm 0.88 *$ & 296 & $2.0 \pm 0.42$ & 87 \\
\hline Pinctada nigra & $0.8 \pm 0.20 *$ & 36 & $0.2 \pm 0.09$ & 8 \\
\hline Pteria penguin & 0 & 0 & $0.2 \pm 0.11$ & 7 \\
\hline Septifer bilocularis & $11.8 \pm 1.79^{*}$ & 508 & $3.8 \pm 1.01$ & 156 \\
\hline Temnotrennci siamense & 0 & 0 & $0.02 \pm 0.024$ & 1 \\
\hline Thalamita prymna & $0.02 \pm 0.023$ & 1 & $0.02 \pm 0.024$ & 1 \\
\hline Tripneustes gratilla & 0 & 0 & $0.02 \pm 0.024$ & 1 \\
\hline Pinna spp. & $1.0 \pm 0.28$ & 46 & $0.5 \pm 0.33$ & 19 \\
\hline Lima spp. & $0.2 \pm 0.07$ & 9 & $0.1 \pm 0.06$ & 5 \\
\hline Majidae & 0 & 0 & $0.05 \pm 0.034$ & 4 \\
\hline Ostreidae & $3.2 \pm 0.34 *$ & 140 & $0.6 \pm 0.17$ & 27 \\
\hline Pectinidae & $0.7 \pm 0.19 *$ & 24 & $0.2 \pm 0.09$ & 8 \\
\hline Sipunculidae & $0.1 \pm 0.06$ & 6 & $1.6 \pm 1.29$ & 6 \\
\hline Trochidae & $0.02 \pm 0.023$ & 1 & 0 & 0 \\
\hline Turbanidae & $0.02 \pm 0.023$ & 1 & 0 & 0 \\
\hline Polychaeta & $0.1 \pm 0.06$ & 6 & $0.3 \pm 0.10$ & 6 \\
\hline Other Crabs & $0.02 \pm 0.023$ & 1 & $0.4 \pm 0.19^{*}$ & 16 \\
\hline Total & $28.2 \pm 20.9$ & 1218 & $10.2 \pm 11.8$ & 438 \\
\hline
\end{tabular}

One $P$. margaritifera and three $P$. penguin were removed from 40 collectors deployed in the Tudor Channel, whereas none was obtained in lagoon study site at the Mombasa MPA. The total macrofauna removed from the collectors ranged from 1 to 127 individuals, the distribution was negatively skewed (Shapiro-Wilks test, $\mathrm{W}=0.834$ $\mathrm{p}<0.001)$ and the variances between seasonal blocks were siginificantly different (Levene's test, $\mathrm{F}=3.372 \mathrm{p}=0.003$ ). The relative abundance of the identified species/taxa is shown in Table 2. Bivalves were more dominant in the Mombasa MPA lagoon, comprising $60.8 \%$ of the total macrofauna, than in the Tudor Channel, where bivalves represented only $36.4 \%$ of the macrofauna removed from collectors. The ascidians, principally Ascidia sydneiensis, and the polychaetes, mainly the tube dwelling worms of the family Sabellidae, were the other abundant taxa removed from the collectors in the Tudor Channel. Other abundant taxa were shrimps and gastropods, which were abundant in the Mombasa MPA samples, and crabs, principally the Portunidae and Xanthidae, which were more abundant in Tudor Channel samples. Sea slugs (Opisthobranchia), mud lobsters (Thallassinidae) and echinoderms (Echinodermata) each made up less than $1 \%$ of the macrofaunal abundance on collectors.

\section{Seasonal occurrence of macrofauna}

The total number of macrofauna obtained from the 43 free nylon rope collectors during the NEM 
Table 2. Abundance of different species/taxa (mean \pm SE) identified from black plastic sheet collectors deployed at Tudor Channel and the Mombasa MPA lagoon in Kenya between April 2004 and April 2005

\begin{tabular}{|c|c|c|c|c|}
\hline & Apr-Jun (A) & Jun-Oct (B) & Oct-Jan (C) & Jan-Apr (D) \\
\hline \multicolumn{5}{|c|}{ Tudor Channel } \\
\hline Pinctada imbricate & $3.8 \pm 0.59$ & $7.5 \pm 2.29$ & $7.3 \pm 2.11$ & $5.9 \pm 1.21$ \\
\hline Pinctada nigra & $0.2 \pm 0.13$ & $0.5 \pm 0.22$ & $0.5 \pm 0.22$ & 0.1 \\
\hline Pteria penguin & $0.2 \pm 0.13$ & 0 & 0 & 0.1 \\
\hline Perna viridis & 0 & 0 & 0.1 & $0.4 \pm 0.16$ \\
\hline Chlamys senatorius & $0.4 \pm 0.22$ & $2.9 \pm 1.53$ & $0.9 \pm 0.52$ & $0.8 \pm 0.48$ \\
\hline Pinna spp. & $0.6 \pm 0.26$ & $1.3 \pm 0.86$ & $2.2 \pm 0.89$ & $0.5 \pm 0.16$ \\
\hline Cymatium muricinum & $0.7 \pm 0.26$ & 0.2 & $0.2 \pm 0.13$ & 0.1 \\
\hline Cymatium spp. & 0 & $0.4 \pm 0.31$ & 0 & 0 \\
\hline Columbella lablosa & 0 & $0.4 \pm 0.22$ & $0.1 \pm 0.1$ & 0 \\
\hline Cypraea helvola & 0 & 0 & $0.6 \pm 0.29$ & 0 \\
\hline Pinctada margaritifera & $0.1 \pm 0.1$ & 0 & 0 & 0 \\
\hline Pteria chinensis & 0 & $0.1 \pm 0.1$ & 0 & 0 \\
\hline Thalamita poisoni & $0.1 \pm 0.1$ & 0 & 0 & 0 \\
\hline Thalamita crenata & $0.1 \pm 0.1$ & 0 & 0 & 0 \\
\hline Thalamita prymna & $1.1 \pm 0.54$ & $0.1 \pm 0.1$ & $0.1 \pm 0.1$ & 0 \\
\hline Placuna spp. & 0 & 0 & $0.6 \pm 0.26$ & $0.1 \pm 0.1$ \\
\hline Gastropoda & $0.6 \pm 0.26$ & $1.0 \pm 0.89$ & $0.3 \pm 0.15$ & $1.1 \pm 0.45$ \\
\hline Ascidiidae & $31.9 \pm 4.79$ & $7.1 \pm 2.30$ & $16.4 \pm 4.86$ & $15.5 \pm 4.15$ \\
\hline Sabellidae & $22.0 \pm 5.31$ & $2.4 \pm 1.22$ & $2.1 \pm 0.80$ & $10.4 \pm 3.16$ \\
\hline Limmidae & 0 & 0 & 0 & 0 \\
\hline Anomidae & $2.5 \pm 0.65$ & $0.3 \pm 0.21$ & $0.4 \pm 0.16$ & $0.8 \pm 0.35$ \\
\hline Echinodermata & 0 & $0.2 \pm 0.13$ & $0.1 \pm 0.1$ & $0.1 \pm 0.1$ \\
\hline Majidae & 0 & $0.5 \pm 0.40$ & $0.3 \pm 0.15$ & $0.1 \pm 0.1$ \\
\hline Galatheidea & 0 & $0.1 \pm 0.1$ & 0 & 0 \\
\hline Opisthobranchia & $0.1 \pm 0.1$ & $0.8 \pm 0.32$ & $0.2 \pm 0.13$ & $1.1 \pm 0.31$ \\
\hline Ostreidae & $0.8 \pm 0.51$ & $5.1 \pm 1.55$ & $8.6 \pm 1.49$ & $8.9 \pm 2.11$ \\
\hline Platyhelminthes & 0 & 0 & $0.2 \pm 0.2$ & $0.1 \pm 0.1$ \\
\hline Polychaeta & $22.0 \pm 5.31$ & $2.4 \pm 1.22$ & $2.7 \pm 0.86$ & $10.8 \pm 3.19$ \\
\hline Portuninae & 0 & $0.4 \pm 0.22$ & $0.2 \pm 0.13$ & $1.0 \pm 0.0 .39$ \\
\hline Sipunculidae & 0 & $0.2 \pm 0.13$ & $0.3 \pm 0.21$ & 0 \\
\hline Thallassinidae & $0.1 \pm 0.1$ & 0 & 0 & 0 \\
\hline Xanthidae & 0 & 0 & $0.4 \pm 0.16$ & 0 \\
\hline Shrimps & $10.1 \pm 0.11$ & $0.3 \pm 0.15$ & $0.2 \pm 0.13$ & $0.7 \pm 0.30$ \\
\hline Other crabs & $1.0 \pm 0.39$ & $0.2 \pm 0.13$ & $0.4 \pm 0.22$ & 0 \\
\hline \multicolumn{5}{|c|}{ Mombasa } \\
\hline Pinctada imbricata & $2.5 \pm 0.57$ & $6.7 \pm 1.85$ & $4.1 \pm 1.25$ & $2.7 \pm 0.47$ \\
\hline Pinctada nigra & 0.1 & $0.5 \pm 0.22$ & $0.5 \pm 0.44$ & 0.1 \\
\hline Malfundus normalis & 0 & 0 & $0.6 \pm 0.44$ & 0.1 \\
\hline Perna viridis & 0 & 0 & $0.2 \pm 0.14$ & 0.1 \\
\hline Chlamys senatorius & 1.4 & $0.8 \pm 0.41$ & $1.2 \pm 0.49$ & 0.1 \\
\hline Pinna spp. & 0.1 & $2.5 \pm 1.43$ & $18.0 \pm 9.00$ & 0 \\
\hline Cymatium muricinum & 0 & 0.1 & $0.3 \pm 0.23$ & 0.1 \\
\hline Cymatium spp. & 0 & 0 & 0 & $1.0 \pm 0.47$ \\
\hline Columbella lablosa & 0 & 0 & $1.6 \pm 0.72$ & 0 \\
\hline Cypraea caputserpentis & 0 & 0 & $0.3 \pm 0.17$ & 0 \\
\hline Malfundus normalis & 0 & 0 & $0.7 \pm 0.44$ & $0.14 \pm 1.14$ \\
\hline Pteria chinensis & $0.1 \pm 0.1$ & 0 & 0 & 0 \\
\hline Tapes lateralis & 0 & 0 & $0.13 \pm 0.125$ & 0 \\
\hline Thalamita prymna & $1.1 \pm 0.63$ & 0 & $0.1 \pm 0.1$ & 0 \\
\hline Marginella sp. & 0 & 0 & $0.1 \pm 0.1$ & 0 \\
\hline
\end{tabular}




Apr-Jun (A) Jun-Oct (B) Oct-Jan (C) Jan-Apr (D)

Tudor channel

Drupella rugosa

Placuna spp.

Gastropoda

Ascidiidae

Sabellidae

Limidae

Anomidae

Echinodermata

Majidae

Galatheidea

Opisthobranchia

Ostreidae

Pectinidae

Platyhelminthes

Polychaeta

Portuninae

Sipunculidae

Strombidae

Thallassinidae

Xanthidae

Shrimps

Other Cypreacea

Other crabs

0
0
0.1
0
$1.2 \pm 0.63$
0
$1.1 \pm 0.45$
0
0
0
0
$2.1 \pm 5.10$
$0.2 \pm 0.13$
$0.1 \pm 0.1$
$1.1 \pm 0.63$
0
0
0
$1.0 \pm 0.72$
0
$2.9 \pm 1.29$
0
0

(a)

$0.1 \pm 0.1$

$0.7 \pm 0.59$

$0.5 \pm 0.16$

$0.5 \pm 0.16$

$0.9 \pm 0.40$

$0.3 \pm 0.21$

$0.6 \pm 1.6$

$0.1 \pm 0.1$

0

0

$0.2 \pm 0.13$

$2.5 \pm 1.17$

$0.1 \pm 0.1$

0

$1.3 \pm 0.55$

0

0

0

0

0

$1.0 \pm 0.37$

$0.2 \pm 0.13$

$0.1 \pm 0.1$

0

$0.1 \pm 0.1 \quad 0.1 \pm 0.1$

$3.2 \pm 0.96 \quad 0.2 \pm 0.18$

$0.1 \quad 0.4 \pm 0.29$

$4.5 \pm 2.03 \quad 0.2 \pm 0.18$

$0.2 \pm 0.2 \quad 0$

$0.1 \pm 0.1 \quad 0$

$0 \quad 0.1 \pm 0.1$

$0.1 \pm 0.1 \quad 0 \pm 0.18$

$0 \quad 0.3 \pm 0.18$

$0.2 \pm 0.14 \quad 0.2 \pm 0.2$

$3.0 \pm 1.77 \quad 0.7 \pm 0.42$

$0.5 \pm 0.5 \quad 0$

$0.3 \pm 0.15 \quad 0.2 \pm 0.13$

$4.6 \pm 2.03 \quad 1.41 \pm 0.82$

$0 \quad 0.9 \pm 0.34$

$0.3 \pm 0.03 \quad 0.1 \pm 0.1$

$0.1 \pm 0.1 \quad 0$

0

$0.4 \pm 0.4 \quad 0$

$\begin{array}{ll}1.3 \pm 0.55 & 3.9 \pm 1.10\end{array}$

0

$0.7 \pm 0.23 \quad 0$

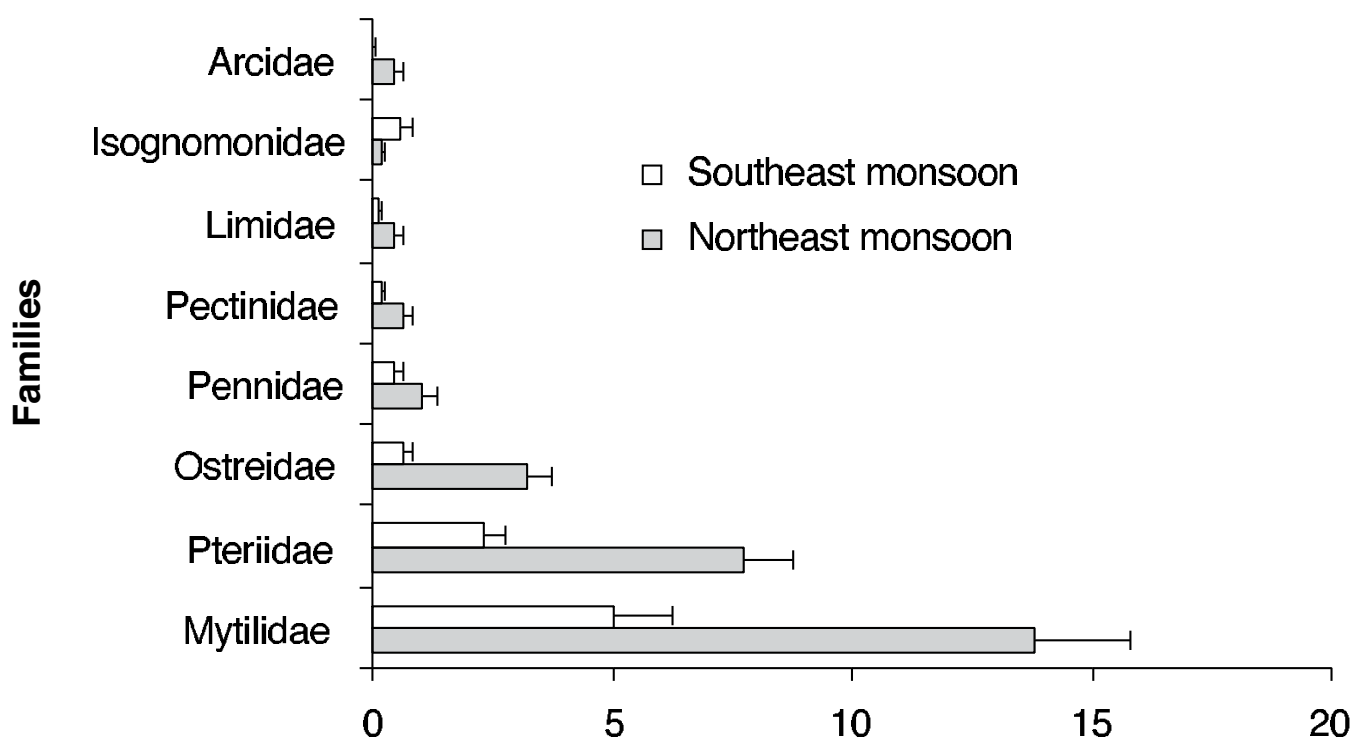

No. per collector

Fig. 2. Abundance of bivalve families (Mean \pm SE) on nylon rope collectors deployed at Kisite during the southeast and northeast monsoon seasons 
season was 1,243 compared to 434 obtained from 41 collectors deployed at the same four sites during SEM season in Kisite (Table 1). The number of macrofauna on each collector ranged from 0 to 84 . Five collectors had no macrofauna, 32 collectors had between 0 and 10 macrofauna, 15 collectors had between 10 and 20 macrofauna, 12 collectors and between 20 and 30 macrofauna, whereas 19 had more than 30 macrofauna. The macrofauna abundance data was not normally distributed (Shapiro-Wilk's W test $=0.854, \mathrm{p}<0.001$ ) and the variance in the SEM and NEM data was not homogenous (Levene's test $\mathrm{F}=9.20, \mathrm{p}=0.003$ ).

The abundance of macrofauna during the NEM season $(28.2 \pm 3.13)$ was significantly higher than during the SEM season $(10.2 \pm 0.85)(Z=4.729$, $\mathrm{p}<<0.05)$. Mytilidae, Pteriidae, Ostreidae and Arcidae were significantly more abundant on collectors during the NEM season than during the SEM season (Mann-Whitney U test, $\mathrm{p}<0.05$ ), (see Figure 2) whereas the Pectinidae, Pennidae, Limidae and were higher during the NEM season than during the SEM season, but the difference was not significant. Species of Isognomonidae were more abundant during the SEM period than during the NEM but the difference was not significant as well.

The mean number of bivalves on nylon rope collectors in Kisite was significantly higher during the NEM season (27.6 \pm 3.04$)$ than during the SEM season $(9.5 \pm 1.66)(\mathrm{Z}=5.10, \mathrm{p}<0.01)$, as shown in Table 1. Twelve species: Barbatia decussata, Chlamys senatorius, Cymatium muricinum, Haliotis pustulata, Musculus cumingiana, Musculus senhousia, P. imbricata, P. nigra, S. bilocularis, Lima lima, Lima spp., Pinna spp. were more abundant during the NEM season. S. bilocularis, one Turbanidae and one Trochidae occurred on the collector during the NEM season only. P. imbricata, $M$. cumingiana and $P$. nigra were significantly more abundant during NEM season $(Z=3.986 \mathrm{p}<0.05$, $Z=4.845, \mathrm{p}<0.05, Z=2.076 \mathrm{p}=0.037$ respectively). Eight species: A. antiquata, Malvufundus normalis, Medaeus granulosus, Pachygrapsus minutus, $P$. viridis, $P$. penguin, Temnotrennci siamense, Tripneustes gratilla were more abundant during the SEM season. Of these, A. antiquata, P. viridis, and $P$. penguin, $P$. minutus, $T$. siamense, $T$. gratilla occured during SEM season only. Six more $P$. penguin spat settled on the 40 nylon rope and onionbag collectors deployed for the collector size-fauna abundance experiment during the SEM season. The Majidae were more abundant during the SEM. $C$. muricinum and some crabs (e.g. Majidae, P. minutus and Medaeus granulosa) that are potential predators of pearl oysters, occurred on the collectors during the SEM season.

The abundance of macrofauna and bivalves removed from black plastic sheet collectors from the lagoon within the Mombasa MPA and in the Tudor Channel during the various sampling times are shown in Figure 3. The abundance of the macrofauna and the bivalves follow a similar pattern at both study sites. However, macrofaunal abundance was highest during the April-June period due to exceptionally high occurrence of ascidians, ranging from 10-50 individuals per collector, during that time. The abundance of macrofauna and bivalves removed from spat collectors recovered from the Tudor Channel was higher than those recovered from the lagoon in the Mombasa MPA during all periods. In Mombasa, the abundance of macrofauna was highest during October-January and the lowest during April-June. The highest bivalve abundance in Mombasa was during the OctoberJanuary period, whereas the lowest abundance was the April-June period. In the Tudor Channel, the period of lowest macrofauna abundance was June-October. This period preceded the period of highest abundance of macrofauna, which was October-January. Bivalves were more abundant in Tudor Channel during October-January than during April-June. However, Kruskal-Wallis tests of macrofauna and bivalve abundances recorded in Mombasa and Tudor Channel showed no significant differences between the periods at $\mathrm{p}>0.05$.

The abundance of common species and/or taxa during the various sampling periods in the Mombasa MPA lagoon and in the Tudor Channel is shown in Table 2. The species Cypraea caputserpentis, $M$. normalis, Tapes lateralis, Marginella sp. and the families Limidae, Pectinidae, and Strombidae only occurred at the lagoon study site, whereas $P$. penguin, Cypraea helvola P. margaritifera, Thalamita poisoni and T. prymna only occurred at the channel study site. The species and the taxa that were present in all study periods in relatively large numbers, included $P$. imbricata, $P$. nigra 


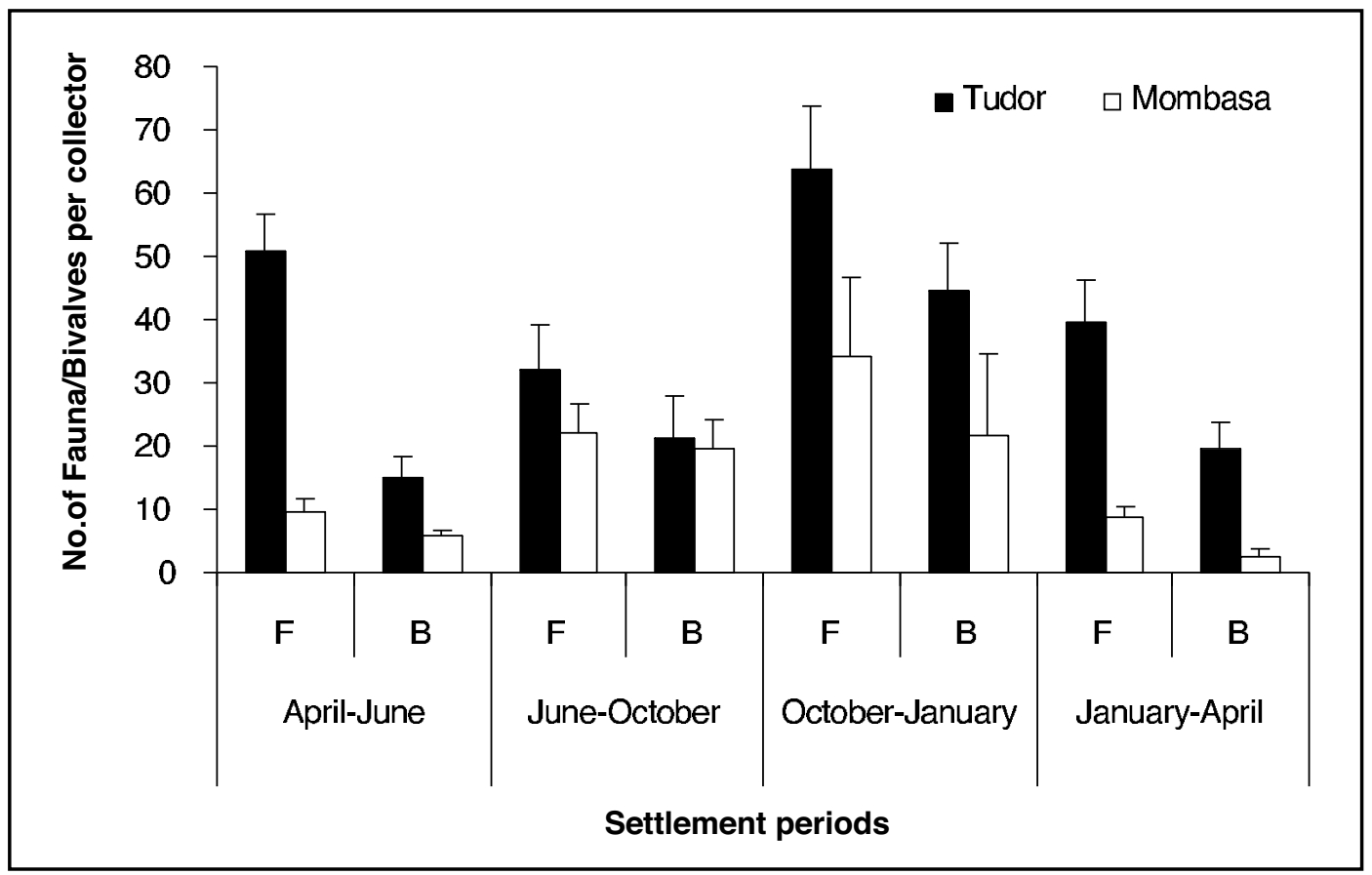

Fig. 3. Macrofauna (F) and bivalves (B) abundance (Mean \pm SE) on collectors deployed in Tudor and Mombasa MPA between April 2004 and April 2005

and C. senatorius, Pinna spp. C. muricinum, polychaetes and gastropods, were more abundant during the June-October and the October-January periods. Ascidians and Sabellidae were abundant on collectors set in Tudor Channel throughout the year and significantly higher $(\mathrm{p}<0.05)$ during the April-June period than all the other periods. In Mombasa, $P$. viridis and $M$. normalis both occurred on collectors deployed between October and April. The Pennidae were more abundant in the OctoberJanuary period and were absent during the JanuaryApril period in Mombasa. Gastropods were always encountered on collectors in low numbers, and were significantly more abundant at Mombasa during the October-January period than the April-June $(Z=2.593, p=0.01)$ and January-April $(Z=2.169$, $\mathrm{p}=0.03$ ) sampling periods. In the Tudor Channel, $P$. penguin occurred on collectors deployed during the January-April and April-June periods, whereas $P$. viridis occurred on collectors set between October and April. The oyster predator, C. muricinum also occurred on collectors regularly in low numbers.

The similarity analysis of samples collected during the four study periods in the Mombasa
MPA lagoon and the Tudor Channel reveal that the Mombasa MPA samples formed seven clusters, with no distinction between samples obtained during sampling periods (global $\mathrm{R}$ value $=0.341, \mathrm{p}$ value $=0.1 \%)$, (see Figure 4A). Among the pair-wise comparisons, only A and B were significantly dissimilar ( $\mathrm{p}$ value $=0.038$ ). SIMPER analysis identified Ostreidae and Pinna spp. to be responsible for 11.36 and $10.06 \%$ of the total dissimilarity between the two sampling periods. The Bray-Curtis similarity dendrogram plots of samples collected during the four study periods in the Tudor Channel (see Figure 4B) showed that samples in A, C and D study periods separated into distinct clusters, whereas samples in study period B separate equally into other clusters, with no significant distinction between samples collected during the four periods (global $\mathrm{R}$ value $=0.378, \mathrm{p}$ value $=0.1 \%$ ). Pair-wise comparisons showed that periods $\mathrm{C}$ and $\mathrm{B}$ were significantly dissimilar ( $\mathrm{p}$ value $=0.026$, while the SIMPER analysis showed that barnacles and sea squirts were responsible for only $12.45 \%$ and $7.41 \%$ respectively, of the total dissimilarity between the two sampling periods. 
(A)

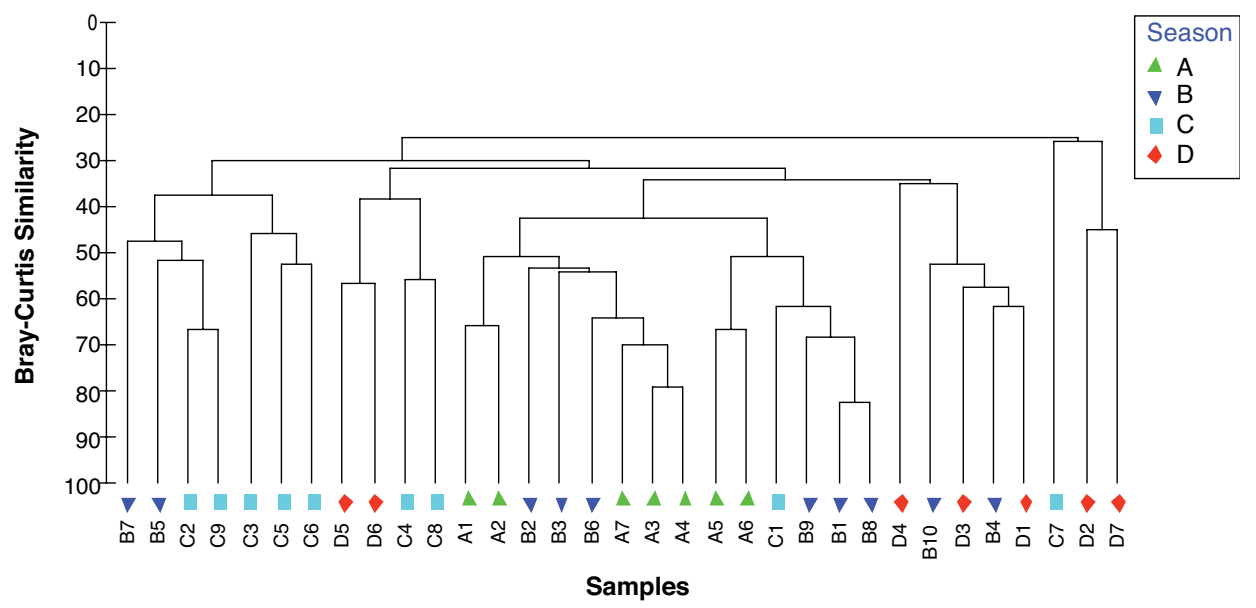

(B)

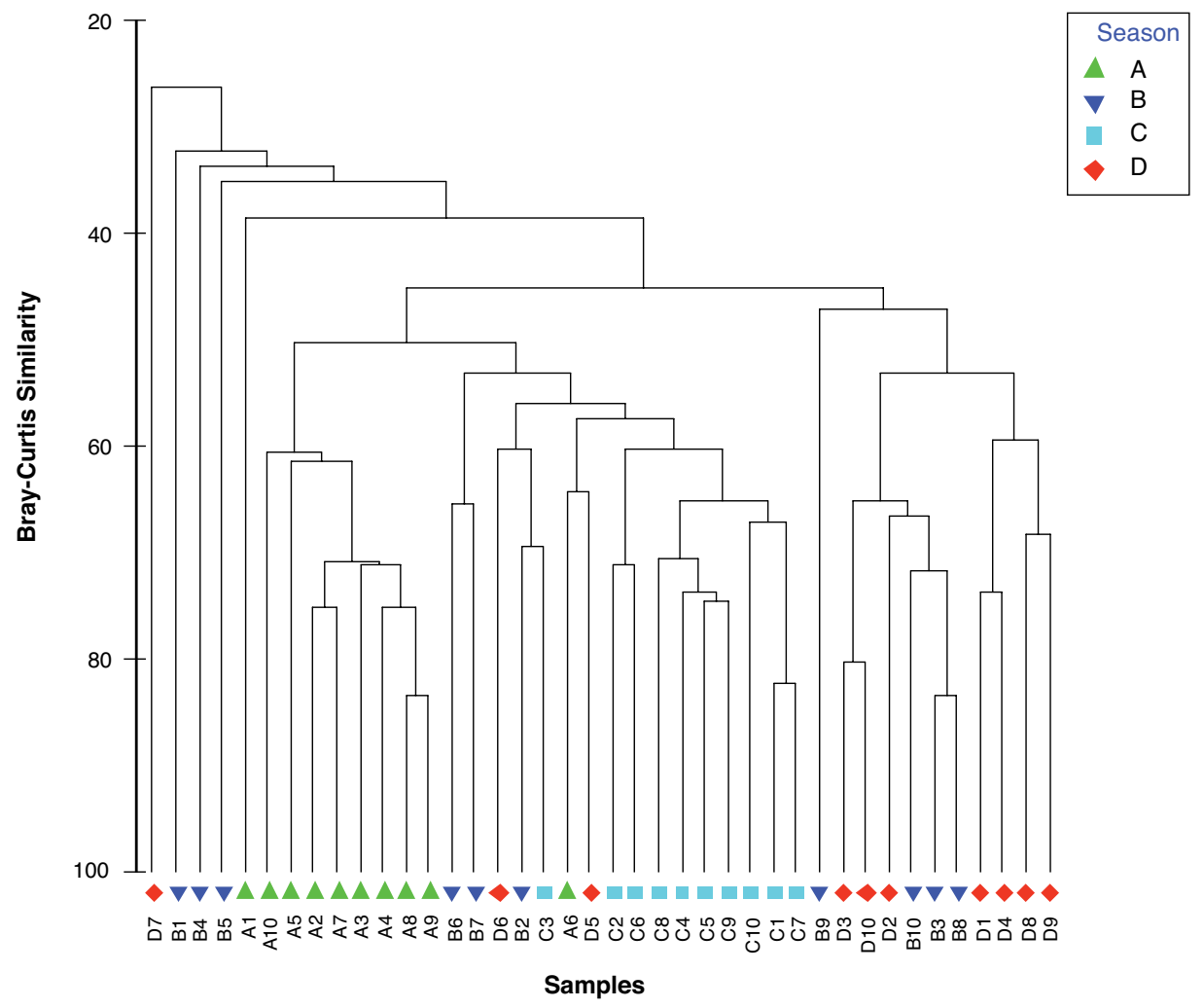

Fig. 4(A). Bray-Curtis similarity dendrogram of samples collected during the four study periods (A=April-June, $\mathrm{B}=$ June-October, $\mathrm{C}=$ October-January, $\mathrm{D}=$ January-April) in Mombasa MPA lagoon site. (B). Bray-Curtis similarity dendrogram of samples collected during the four study periods $(A=A$ pril-June, $B=J u n e-O c t o b e r, ~ C=O c t o b e r-J a n u a r y$, D=January-April) in the Tudor channel site 


\section{Size of collector}

The abundance of all macrofauna bivalves and gastropods on different sizes of nylon rope and onion-bag collectors set in Kisite is shown in Figure 5. The distribution of the macrofauna from 40 collectors was not normal (Shapiro-Wilkes test, $\mathrm{W}=0.900, \mathrm{p}<0.001$ ) and the variance among collector sizes was only marginally homogenous (Levene's test, $\mathrm{p}=0.052$ ). The abundance of macrofauna increased with the relative size of collector for the nylon rope as well as the onionbag net collectors. However, the mean number of species did not increase with the relative size of collector and was almost constant between $4.3 \pm 0.76$ and 5.3 \pm 2.6 for nylon rope collectors and varied from $3.1 \pm 0.54$ to $7.0 \pm 0.89$ species for the onion- bag net collectors. The highest mean number of settled macrofauna was on half-size onion-bag net collectors $(81.0 \pm 32.89)$ and on the 3 nylon rope bundles (57.0 \pm 19.50$)$. The high mean for half onion-bag collectors was due to a large number of mussels on two collectors (149 and 138). Removing the two samples from the data set revealed a clearer pattern of increasing mean abundance with size of collector for both types of collectors. The mean number of macrofauna increased dramatically from $25.7 \pm 6.7$ for bundles of two nylon rope collectors to $57.0 \pm 19.50$ for bundles of three collectors. However, Kruskal-Wallis median tests of the macrofauna, bivalves and bivalve species data for the different sizes of collectors gave no significant difference at $p>0.05$, except between one and four bundles of rope collector where a marginally

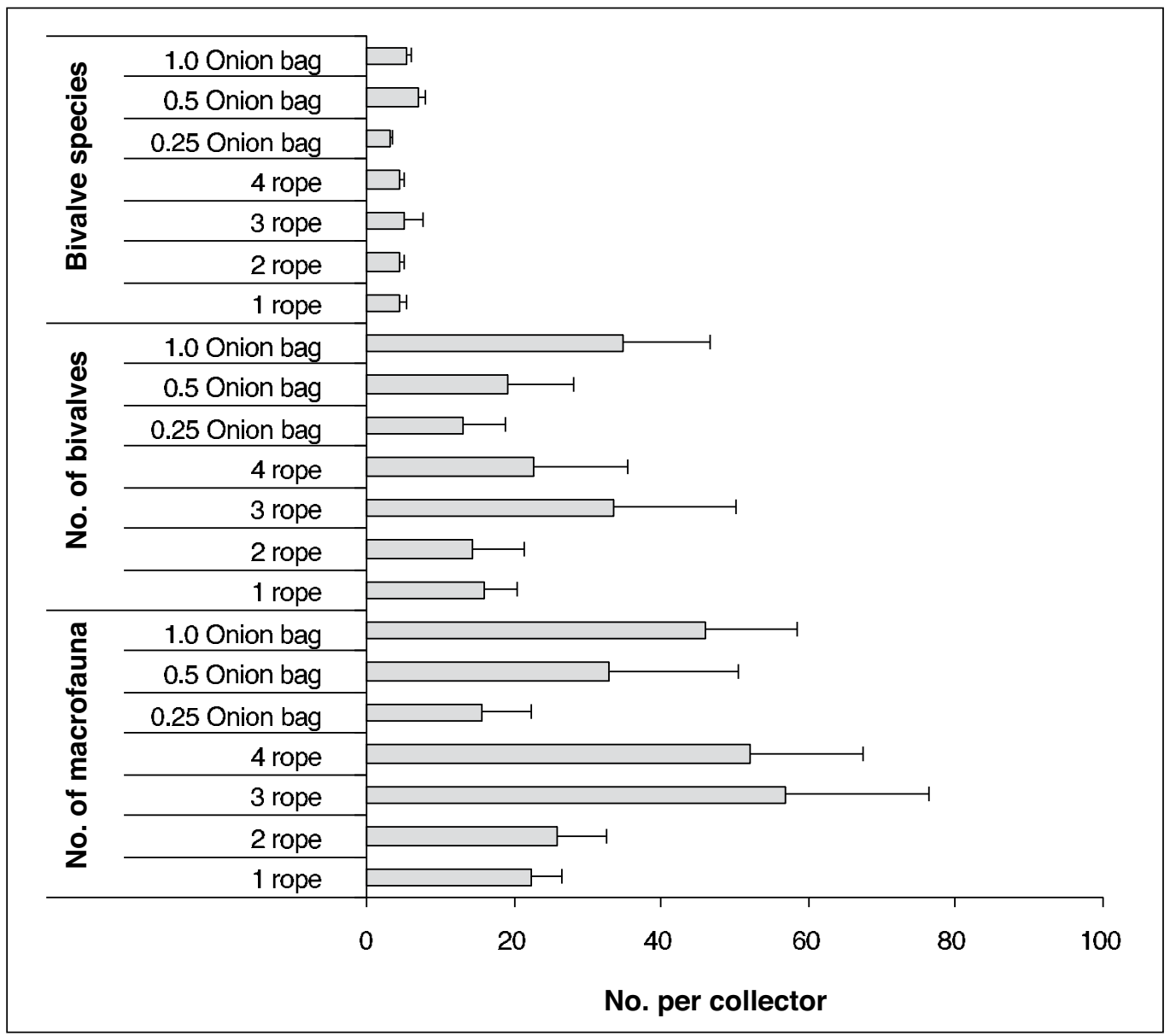

Fig. 5. Mean number of bivalve species, bivalves and macrofauna ( \pm SE) per collector on different sizes of nylon rope and onion-bag collectors in Kisite from 12-19 March to 9 September 2003. Note: Collector sizes were one, two, three and four bundles of $45 \mathrm{~cm}$ long $10 \mathrm{~mm} \emptyset$ nylon rope. Onion-bag sizes were $1 / 4,1 / 2$ and full size onion-bag $(34 \times 74 \mathrm{~cm})$ 
significant difference was achieved $(Z=2.142$, $\mathrm{p}=0.03$ ). The variation of bivalve numbers data was extremely high resulting in no statistical difference among the collector sizes.

\section{DISCUSSION AND CONCLUSION}

\section{Abundance and seasonality of pearl oysters}

The most abundant pearl oyster in this study was $P$. imbricata, a small non-commercial species common in lagoons throughout the Indo-Pacific oceans. Its abundance is similar to the three oysters per collector obtained in the Caribbean (Urban, 2000a). The periods of high settlement, during the NEM season, coincided with the periods of intensive spawning (Urban, 2000b; Kimani et al., 2006), indicating that the settling larvae are likely to be from the local spawning population. Settlement of Pinctada spp. (most likely P. imbricata) in Tanzania was highest between November and December, during the NEM season (Bwathondi \& Ngoile, 1982). $P$. margaritifera was found on the collectors in the Tudor Channel only in June 2004. Other studies show much higher spatfall, between two and six $P$. margaritifera per collector in the Solomon Islands (Friedman \& Bell, 2000), and a range of 20-300 per collector in French Polynesia (Coeroli et al., 1984; SPC Pearl Oysters Information Bulletin, 1998). The low settlement in this study might be explained by unsuitable collector materials, unsuitable study sites or low natural recruitment during the study period. Synthetic nylon rope used throughout the trials was found to be a poor collector material for pearl oysters (Victor et al., 1987). However, plastic sheets and onion-bag net materials also gave the same poor result. In the Solomon Island study, the best results were achieved in sites with clear water, moderate currents, $>15 \mathrm{~m}$ depth, and at least $35 \mathrm{~m}$ from the nearest reef (Friedman \& Bell, 2000). The conditions at the study area at Kisite were closest to these, yet no $P$. margaritifera were recorded on the spat collectors set in that location.

Low recruitment of $P$. margaritifera spat on collectors has however been observed in other studies, Rodgers et al. (2000) in Hawaii, Knuckley (1995) in Australia, and Monteforte \& Garcia-
Gasca (1994) for Pinctada mazatlanica in Mexico. In the present study, even in areas with relatively high P. margaritifera densities, such as Gazi and Shimoni field observations revealed very few spat oysters $<60 \mathrm{~mm}$ among the natural population. The reason for the poor recruitment on collectors therefore appears to be the low natural recruitment during our study period. From the settlement and the population structure data, the recruitment of $P$. margaritifera in East Africa appears to be episodic. Episodic recruitment was noted for the sea urchin E. mathaei in Kenya (Muthiga, 1996) and for the oyster S. cucullata in South Africa (Dye, 1990). The long-term monitoring of recruitment patterns to determine the environmental and oceanographic factors that favour recruitment episodes may help in the understanding and prediction of recruitment patterns of the commercial pearl oysters in the Western Indian Ocean region. Further studies might include examining the gonad condition of potential spawners in the wild to determine the period of greatest spawn potential.

$P$. penguin was recorded on the collectors in relatively small numbers at Kisite and in the Tudor (Tables 1 and 2). This species is harvested for the shell ornaments in the Solomon Islands and cultured for hemispherical pearls in the Fiji Islands, Borneo (Wada, 1973) and Thailand (Saraya, 1982). The species also supports a successful spherical pearl culture in the Philippines (Kanjanachatree et al., 2003). The species is therefore a good alternative for pearl culture in Western Indian Ocean. Other species of commercial value that were recorded are the edible oysters of the family Ostreidae, which occurred in large numbers, and the mussel $P$. viridis and cockles $A$. antiquata and B. decussata. Cockles are collected and eaten in Kenya (ENK pers. obs.) and might be cultured (e.g. Kayombo, 1991) as a supplementary business to augment the value of pearl oyster seed collection operations.

\section{Abundance and seasonality of macrofauna}

This study demonstrates the range and abundance of species that may be collected on artificial materials for seed collection as well as for ecological and recruitment studies in the Western Indian Ocean. Bivalves dominated the species diversity as well 
as the abundance of fauna recruited to the spat collectors, as also shown in other studies (Knuckey, 1995; Thouzeau, 1991). However, the relative species abundance depended on the habitat, for instance, polychaetes were more abundant on collectors set in the Mombasa lagoon than on collectors set in Kisite. Prawns and gastropods were relatively more abundant in the Mombasa lagoon, whereas the ascidians and polychaetes were more abundant in the Tudor Channel. The relative abundance of commercially important bivalves including species of the Mytilidae, Pteriidae and Ostreidae were particularly high in Kisite, similar to number reported from Northern Australia, where the Mytilidae, Pteriidae and Pectinidae dominated bivalves on collectors (Knuckey, 1995). However, a small inedible species Musculista glaberrima made up the bulk of the Mytilidae in the above study. In contrast, crustaceans were found to dominate communities on monofilament nylon gillnet collectors in California, Mexico (Monteforte and Garcia-Gasca, 1994).

The settlement data collected in this study reveals marked seasonal patterns for some species. In general, the settlement of bivalves was higher during the NEM season, with a few exceptions that settle on collectors during the SEM season. However, a few species settle throughout the year as well as during the cooler months of the SEM season. The results of the multivariate analysis indicate more distinct assemblages, in the channel environment, during the four sampling periods and less distinct assemblages in the open lagoon environment. The channel environment is influenced more by fresh water and sediment input than the lagoon environment (Mavuti et al. 2005). This may explain the more distinct macrofauna assemblages on collectors during the sampling times.

\section{Influence of collector size}

The size of collectors is important because of cost, and the choice between cost and the relative benefits of deploying a few large collectors, or many small collectors must be made. The experiments conducted in the present study showed greater numbers of macrofauna (including bivalve) on larger collectors, due to the larger surface area available. However, the increase in settlement was not proportional to the increase in collector size. Similarly, Friedman \& Bell (2000) found more spat of $P$. margaritifera on small pieces of shade-mesh material compared to large single piece of the same surface area. Although it may be easier and cheaper to deploy large collectors, small collectors achieve higher macrofaunal settlement per unit size.

This study has shown that a range of species, in particular bivalves, settle on collector materials in Kenya. The NEM season favors more abundant settlement for the bivalve species that settle all the year round. However, some species, including $P$. penguin, settle only during the SEM season. Seasonality of macrofauna assemblages on collectors is more distinct in the channel environment that the open lagoon environment.

Acknowledgements - We acknowledge the director of Kenya Marine and Fisheries Research Institute (KMFRI) Dr Johnson Kazungu, for according the first author leave to conduct field work for this research. We thank Dr Nyawira Muthiga for inspiring and supporting this work in many ways. The assistance of Mr Masudi Juma in the field and Ms Mary Nkono in the laboratory are highly appreciated. This work was funded and supported by KMFRI, VLIR-IUC-UoN staff development and training project of the University of Nairobi, and the International Fund for Science Project no. A/3360-1.

\section{REFERENCES}

Abbott, R.T. \& Dance, S.P. (1982) Compendium of seashells. E. P. Dutton, New York pp. 410.

Bwathondi, P.O.J. \& Ngoile, M.A.K. (1982) Bivalves fouling floating cages used in aquaculture. Indian J. Mar. Sci., 11: 283-285.

Cabral, O.K., Mizuno, \&. Tauru.,A. (1985) Preliminary data on the spat collection of mother of pearl (Pinctada margaritifera, Bivalve, Mollusc) in French Polynesia. In: Delasalle, B., R. Galzin, B. Salvat, C. La Croix, A. E. Wolf, N. Thiebaut, G. Poli (eds.). Proc. $5^{\text {th }}$ Int. Coral Reef Congress Vol. 5 International Association for Biological Oceanography, Tahiti. pp 177-182.

Cashmore, D., Learmouth, M.C.G. \& MacMillan, J.T. (1998) Improving the efficiency of wild Pecten maximus spat collection: potential effects of spat bag design and of species temporarily settling in 
spat bags. Aquaculture, 160: 273-282.

Coeroli, M., De Gaillande, D. \& Landret, J. P. (1984) Recent innovations in the cultivation of mollusks in French Polynesia. Aquaculture, 39: 45-67.

Dye, A.H. (1990) Episodic recruitment of the rock oyster Saccostrea cucullata (Born, 1778) on the Transkei coast. S. Afri. J. Zool., 25(3): 185-187.

Friedman, K.J. \& Bell, J.D. (2000) Short immersion times increase yields of the blacklip pearl oyster, Pinctada margaritifera (Linne.) from spat collectors in Solomon Islands. Aquaculture, 187: 299-313.

Haven, D.S. \& Fritz, L.W. (1985) Setting of the American oyster Crassostrea virginica in James River, Virginia, USA: temporal and spatial distribution. Mar. Biol., 86: 271-286.

Kanjanachatree, K., K. Piyathamrongrut \& Inthonjaroen, N. (2003) Sea depths and sizes of the winged oyster on pearl culture. Songklanakarin J. of Sci. and Tech., 25: 659-671.

Kayombo, N.A., (1991) A system for experimental farming of the edible bivalve Anadara antiquate (Linnaeus, 1758) in Tanzania. In: K. Koop (ed). Proceedings of a Workshop on Research in Aquaculture in Africa. 23-27 January 1991, Harare, Zimbabwe, pp. 57-71.

Kimani, E.N., Mavuti, K.M. \& Mukiama, T. (2006) The reproductive cycle of the pearl oyster Pinctada imbricata in Gazi bay, Kenya. Tro. Zool. 19: 159-174.

Knuckey, I.A. (1995). Settlement of Pinctada Maxima (Jameson) and other bivalves on artificial collectors in the Timor Sea, Northern Australia. $J$. Shellfish Res., 14: 411-416.

Mavuti, K.M., Kimani, E.N. \& Mukiama, T.K. (2005). The growth patterns of the pearl oyster Pinctada margaritifera in Gazi bay, Kenya. Afr. Jou. Mar. Sci. 27(3): 567-575.

Monteforte, M. \& Garcia-Gasca, A. (1994) Spat collection studies on pearl oysters Pinctada mazatlanica and Pteria sterna (Bivalvia, Pteriidae) in Bahia de La Paz, South Baja California, Mexico. Hydrobiologia, 291: 21-34.

Muthiga, N.A. (1996) The role of early life history strategies on the population dynamics of the sea urchin Echinometra mathaei (de Blainville) on the reefs in Kenya. Ph.D. Thesis, University of Nairobi. 252 pp.

Rice, M.A., Mmmochi, A.J. Zubieri, L. \& Savoie R.M. (2006): Aquaculture in Tanzania. World Aquaculture 37(4): 50-57.

Richmond, M.D. \& Rabesandratana, H.D. (1997) A guide to the seashores of East African and the Western Indian Ocean Islands. Sida, SAREC, Stockholm, Sweden. 448 pp.

Rodgers, S.K, Sims, N.A.. Sarver D.J. \& Cox, E.F.
(2000) Distribution, recruitment and growth of the blacklip pearl oyster, Pinctada margaritifera, in Kane'ohe Bay, O' ahu, Hawai'i. Pacific Sci., 54(1): 31-38.

Rose, R.A. \& Baker, S.B. (1994) Larval and spat culture of the western Australia silver or goldlip pearl oyster, Pinctada maxima Jameson (Mollusca: Pteriidae). Aquaculture, 126: 35-50.

Saraya, A, (1982) Country Reports: Thailand. In: Davy, F.B. \& Graham, M. (eds.). Bivalve culture in Asia. Pacific International Research Center for Development. Attawa. pp 73-78.

Shirai, S. (1994): Pearls and pearl oysters of the world. Marine Planning, Okinawa. pp 108.

Sims, N.A. (1993) Pearl Oysters. In: Wright A. and Hill A. (eds). Nearshore resources of the South Pacific. Honiara (Solomon Islands), Suva (Fiji): Forum Fisheries Agency (FFA) Institute of Pacific Studies (IPS). Singapore National Printers. pp 408-430.

SPC Pearl Oyster Information Bulletin. (1998) Pearl world news update. The farming and marketing of Tahitian black pearls. Pg 11-13.

Southgate, P.C. \& Beer, A.C. (1997) Hatchery and early nursery culture of the blacklip pearl oyster (Pinctada margaritifera L.). J. Shellfish Res., 16(2): 561-567.

Sumpton, W.D., Brown, I.W. \& Dredge, M.C.L. (1990) Settlement of bivalve spat on artificial collectors in a subtropical embayment in Queensland, Australia. J. Shellfish Res., 9: 227-231.

Thouzeau, G. (1991) Experimental collection of postlarvae of Pecten maximus (L.) and other benthic macrofaunal species in the bay of SaintBrieuc, France. 1. Settlement patterns and biotic interactions among the species collected. J. Exp. Mar. Biol. Ecol., 148: 159-179.

Urban, H.J. (2000a) Culture potential of the pearl oyster (Pinctada imbrica) from the Caribbean. II. Spat collection, growth and mortality in culture systems. Aquaculture, 189: 375-388.

Urban, H.J. (2000b): Culture potential of the pearl oyster (Pinctada imbrica) from the Caribbean.1. Gametogenic activity, growth, mortality and production of a natural population. Aquaculture, 189: $361-373$.

Van Someren, V.D. \& Whitehead, B.A. (1961) An investigation of the biology and culture of an East African oyster Crassostrea cucullata. Fish. Publ. Lond., 14: 1-41.

Victor, A.C.C., Chellam, A. \& Dharmaras, S. (1987) Pearl oyster spat collection. Bull. Cent. Mar. Fish. Res. Inst., 39: 49-53.

Wada, K.T. (1973) Modern and traditional methods of pearl culture. Underwater Journal, 5(1): 21-28. 